bibwym@utp.edu.pl

Biblioteka Główna Uniwersytetu Technologiczno-Przyrodniczego

w Bydgoszczy

\title{
REPOZYTORIUM UCZELNIANE, BUDOWA I KOORDYNACJA JEGO DZIALANIA SZANSĄ NA WZMOCNIENIE POZYCJI BIBLIOTEKI W REALIZACJI MISJI NAUKOWO-EDUKACYJNEJ UCZELNI
}

\begin{abstract}
The purpose of this paper is to present educational tasks support from the university library. By building and coordinating the functioning of the university repository it can be actively involved in the promotional activities, which as a result of developments in the education market, can make the school better. Open Access and Open Educational Resources are still dominant trends in the publication of the results of scientific research and didactics. The role of the university is also the production and processing of knowledge. Knowledge is located in the center of the knowledge society. It is guaranteed the creation and development of such a model of society. Repositories are the component of modern education as well as knowledge transfer and sharing. The effort of the part of the university library in the implementation of these models of scholarly communication and education methods is an opportunity to strengthen its place in the structure of the university. The task to provide adequate information has not changed. The users prefer the resources available in the network. Nevertheless, they still need a professional support that can provide library staff. The author of the text attempt to show the location of educational materials in the repository. The basis for discussion was the chosen literature in the field of Open Access and Open Educational Resources as well as their own observations.
\end{abstract}

Słowa kluczowe: repozytorium instytucjonalne, biblioteki szkół wyższych, edukacja, materiały dydaktyczne

\section{Przewaga konkurencyjna uczelni wyższej}

Podstawowym zadaniem uczelni wyższej, obok prowadzenia badań naukowych, jest edukacja studentów. Dziś główny nacisk kładzie się na to, by kształcenie było skorelowane z potrzebami gospodarki. Tworzone są nowe kierunki, uruchamia się system stypendiów (tak zwane kierunki zamawiane). Podejmuje się współpracę z przemysłem, nie tylko w celu komercjalizacji wyników pracy naukowej, ale też dla zapewnienia praktyk studentom czy nawet, w przyszłości, pracy dla wybitnych absolwentów. Wzrasta w społeczeństwie świadomość, że czas studiów nie jest przedłużeniem młodości, ale konkretną inwestycją w przyszłość. Dobre studia nie oznaczają automatycznie 
dobrej, rozumianej często jako dobrze płatnej, pracy $^{1}$. Od kilku lat w mediach mówi się o bezrobotnych absolwentach, bezużyteczności dyplomu licencjata czy magistra. Teraz teza ta zbiera swoje żniwa. Młodzi zamiast zdobywać tytuły, wolą się kształcić w konkretnych zawodach albo od razu podjąć pracę uważa Paweł Zygarłowski, prezes Centrum Rozwoju Szkół Wyższych TEB Akademia ${ }^{2}$.

Dużym wyzwaniem dla uczelni wyższych w Polsce stał się niż demograficzny. Uczelnie o ustalonej renomie, często mieszczące się w wielkich aglomeracjach nie odczuwają dotkliwie problemu niedoboru studentów, mniejsze uczelnie muszą walczyć o przetrwanie. Obok niżu demograficznego, w literaturze opisującej problem zmniejszającej się liczby osób studiujących ${ }^{3}$, wymienia się między innymi malejącą liczbę studentów zaocznych, złą sytuację gospodarczą kraju, która skutkuje bezrobociem wśród absolwentów szkół wyższych, czy konkurencję uczelni europejskich, których dostępność wzrosła wraz z wejściem Polski do Unii Europejskiej. Szkoły wyższe muszą budować swoją konkurencyjną przewagę, element podstawowy w gospodarce rynkowej, skutecznie przekonywać otoczenie o swojej randze. Na przewagę konkurencyjną uczelni składa się szereg elementów, takich jak oferta edukacyjna, kadra, wartość rynkowa absolwentów, działalność badawcza, czy baza naukowo-techniczna, do której zaliczana jest biblioteka uczelniana ${ }^{4}$, niestety na równi z salami dydaktycznymi i pracowniami komputerowymi ${ }^{5}$.

Zabiegi promocyjno-marketingowe stają się koniecznością, zarówno w świecie realnym, jak i wirtualnym. Internet jest często pierwszym źródłem informacji, dlatego wrażenie odniesione po odwiedzinach strony internetowej uczelni, ma zasadnicze znaczenie. Potencjalny kandydat na studia szuka na stronie WWW oferty edukacyjnej, zasad rekrutacji, wiadomości o wsparciu między innymi materialnym, na które może liczyć w czasie studiów. Mimo, że biblioteka nie sytuuje się zbyt wysoko w rankingu czynników branych pod uwage przy wyborze uczelni ${ }^{6}$, jej obecność na stronie internetowej, jest sygnałem, że zajmuje ona ważne miejsce w strukturze uczelni. Przykłady, gdzie

\footnotetext{
${ }^{1}$ Tylko w ciągu czterech lat liczba studentów spadła o okokło 400 tys. osób. Dyplom nie jest gwarancją sukcesu - informuje „Dziennik Gazeta Prawna”. Ostatnie dane GUS pokazują, że obecnie w szkołach wyższych kształci się zaledwie 1,469 mln osób. Tymczasem z prognoz Ministerstwa Nauki i Szkolnictwa Wyższego wynika, że liczba studentów miała spaść poniżej 1,5 mln dopiero w roku akademickim 2016/2017; [dostęp:14.04.2015], http://tvn24bis.pl/ z-kraju,74/studia-sa-passe-mlodzi-wybieraja-prace,533147.html.

${ }^{2}$ Ibidem.

${ }^{3}$ M. Czyżewska, Wizerunek biblioteki a przewaga konkurencyjna szkót wyższych, [w:] Kształtowanie wizerunku biblioteki, Białystok 2007, s. 53.

${ }^{4}$ P. Ratajczak, B. Sojkin, Ksztaltowanie pozycji konkurencyjnej szkoty wyższej i jej oferty edukacyjnej, [w:] Marketing szkót wyższych, Poznań 2004, s. 161-166.

${ }^{5} \mathrm{P}$. Spychała, M. Szlachcic, T. Wudarzewski, Wykorzystanie aktywnych form dydaktycznych $w$ działalności promocyjnej uczelni, [w:] Marketing szkót wyższych, Poznań 2004, s. 307.

${ }^{6} \mathrm{P}$. Zeller, Proces oceny jakości ustug szkoty wyższej z perspektywy studenta, [w:] Marketing szkół wyższych, Poznań 2004, s. 226.
} 
biblioteka jest doceniana w taki sposób nie są wcale rzadkie. Ale nie brakuje też tych, gdzie obecność biblioteki w strukturze uczelni jest traktowana jedynie jako spełnienie ustawowego wymogu. $\mathrm{W}$ interesie biblioteki jest uświadomienie władzom uczelni potencjału, jakim ona dysponuje. Zintensyfikowanie działań ukierunkowanych na pomoc studentom $\mathrm{w}$ nauce $\mathrm{w}$ postaci materiałów dydaktycznych może być postrzegane w kategoriach promocji całej uczelni. Jednak to przede wszystkim biblioteka sama musi sobie ten potencjał uświadomić.

\section{Open Access}

Podstawy Open Access (OA) zostały zawarte w trzech deklaracjach: Deklaracji Budapesztańskiej (Budapest Open Access Initiative, luty 2002 r. ${ }^{7}$, Deklaracji z Bethesda (Bethesda Statement on Open Access Publishing, czerwiec 2003 r.) ${ }^{8}$ oraz Deklaracji Berlińskiej (Berlin Declaration on Open Access to Knowledge in the Sciences and Humanities, październik 2003 r.) $)^{9}$, tak zwane $\mathrm{BBB}^{10}$. Mówi się w nich o zniesieniu wszelkich ograniczeń na rzecz otwartego dostępu. Jest on darmowy, każdy zainteresowany ma prawo czytać, kopiować, rozprowadzać, drukować, przeszukiwać i używać w dowolnym innym celu materiały, ale zgodnie $\mathrm{z}$ prawem autorskim. W dostępie tym nie ma ograniczeń finansowych czy technicznych. Przeszkodą może być tylko sam brak możliwości korzystania $\mathrm{z}$ sieci Internet. Autor, udostępniając pracę $\mathrm{w}$ wolnym dostępie ma prawo do zapewnienia dziełu integralności i oznaczenia jej w wybrany przez siebie sposób. Decyzja autora jest tu kluczowa. Do niego należy określenie zakresu udostępniania utworu. Wymaga to uświadomienia sobie przysługujących praw i pełniejszego z nich korzystania, niż w tradycyjnym modelu publikowania, gdzie wszelkie prawa musiały być scedowane na wydawnictwo ${ }^{11}$.

Wolny dostęp do zasobów naukowych, jako jedną z dróg do innowacyjnego społeczeństwa, zaleca Unia Europejska ${ }^{12}$. Publikacje finansowane przez Europejską Radę ds. Badań Naukowych (European Research Council, ERC) powstałe $\mathrm{w}$ ramach programu Horizon $2020^{13}$ mają być umieszczane

\footnotetext{
${ }^{7}$ Budapest Open Access Initiative, [dostęp: 10.04.2015], http://www.soros.org/open access.

${ }^{8}$ Bethesda Statement on Open Access Publishing, [dostęp: 10.04.2015], http://dash. harvard.edu/bitstream/handle/1/4725199/suber_bethesda.

${ }^{9}$ Berlin Declaration on Open Access to Knowledge in the Sciences and Humanities, [dostęp: 10.04.2015], http://oa.mpg.de/lang/en-uk/berlin-prozess/berliner-erklarung.

${ }^{10}$ P. Suber, Otwarty dostęp. Warszawa 2014, s. 19, [dostęp: 10.04.2015], http:// pon.edu.pl/index.php/nasze-publikacje?pubid=14.

${ }^{11}$ Ibidem, s. 30.

${ }^{12}$ Open Access Guidelines for research results funded by the ERC, [dostęp: 14.04.2015], http://erc.europa.eu/sites/default/files/document/file/ERC_Open_Access_Guidelines-revised_20 14.pdf.

${ }^{13}$ Horyzont 2020, [dostęp: 14.04.2015], http://www.nauka.gov.pl/horyzont-2020/.
} 
w otwartych repozytoriach. Na poziomie narodowym większość badań jest finansowana ze środków publicznych, a mimo to dostęp do ich wyników jest utrudniony. To pociąga za sobą wyższe koszty prac badawczych, ogranicza ich poziom. Obniża tym samym skalę współpracy naukowej, zarówno krajowej, jak i międzynarodowej ${ }^{14}$. Mimo szeregu stwierdzeń o pozytywnym wpływie otwartego dostępu na naukę, brak jest w kraju jednolitego aktu prawnego. Wiele jednak zależy od działań oddolnych. Bożena Bednarek-Michalska ${ }^{15}$ wprost zachęca biblioteki akademickie do wychodzenia $\mathrm{z}$ inicjatywą do środowiska naukowego własnej uczelni. Mogą one zapewnić pomoc przy gromadzeniu publikacji w postaci elektronicznej, oferowanie długoterminowej archiwizacji w celu zabezpieczenia dorobku naukowego, prowadzenie szkoleń dla pracowników i studentów z zakresu wyszukiwania i wykorzystania otwartych zasobów, wskazywanie pozytywnych przykładów funkcjonowania modelu OA i tym samym zachęcanie do stosowania go we własnej pracy naukowobadawczej.

Podstawą kariery w polskim systemie szkolnictwa wyższego jest między innymi publikowanie w uznanych czasopismach tradycyjnych, dostępnych najczęściej za opłatą. Błędne przekonanie, że umieszczanie prac w repozytorium wyklucza publikowanie $\mathrm{w}$ tradycyjnej formie, a do tego narusza prawo autorskie, jest przyczyną zachowawczego podejścia wielu twórców do otwartego dostępu ${ }^{16}$.

Środowisko bibliotekarskie, często najbardziej zorientowane w tematyce nowej komunikacji naukowej, może aktywnie przejąć zadanie implementacji reguł OA w swojej uczelni. Jak pokazuje praktyka, to biblioteka inicjuje wydanie przez władze uczelni odpowiednich aktów, które powoływałyby do istnienia repozytorium i regulowały jego funkcjonowanie.

\section{Otwarta nauka a edukacja}

Open Access stał się inspiracją dla ruchu Otwartej Edukacji. Otwarte Zasoby Edukacyjne (OZE) powstające w jego ramach są rekomendowane przez Radę Europy, jako sposób na walkę z wykluczeniem cyfrowym i na wyrównywanie szans edukacyjnych ${ }^{17}$. Terminem OZE określa się powszechnie dostępne

${ }^{14}$ J.W. Hofmokl, Przewodnik po otwartej nauce, Warszawa 2009, s. 59, [dostęp: 14.04.2015], http://creativecommons.pl/wp-content/uploads/2012/06/Przewodnik_Po_Otwartej_ Nauce.pdf.

${ }^{15} \mathrm{~B}$. Bednarek-Michalska, Rola bibliotek naukowych we wdrażaniu rozwiazań otwartych. Repozytorium Open Access - model dla uczelni, [w:] Otwarte zasoby wiedzy. Nowe zadania uczelni i bibliotek w rozwoju komunikacji naukowej. Materiały konferencyjne. Kraków 2011, s. 48-49, [dostęp:14.04.2015], http://www.nowyebib.info/images/stories/Mat_konferencyjne/23/ konferencjaozw_2011_calosc.pdf.

${ }^{16}$ P. Suber, op. cit., s. 55-56. edukacja/.

${ }^{17}$ Koalicja Otwartej Edukacji, [dostęp: 8.04.2015], http://koed.org.pl/otwartosc/otwarta- 
zasoby, takie jak: podręczniki, kursy, scenariusze lekcji i inne, udostępniane za darmo wraz z odpowiednią licencją pozwalającą na ich wykorzystanie i dalsze przetwarzanie. Najpopularniejszym sposobem licencjonowania OZE są licencje Creative Commons (CC) ${ }^{18}$. Konstrukcja licencji CC pozwala udostępniać prace na korzystnych zasadach zarówno dla autora, jak i użytkownika. Autorzy artykułu Open AGH - otwarte zasoby edukacyjne w praktyce ${ }^{19}$ powołując się na raport Massachusetts Institute of Technology (MIT) OpenCourseWare $^{20}$ z 2006 r., wskazują na następujące korzyści OZE: poprawę jakości kształcenia, zwiększenie prestiżu i zasięgu oddziaływania uczelni, zainteresowanie wśród potencjalnych studentów MIT. Dodają jeszcze łatwość adaptacji w przypadku materiałów nieopatrzonych warunkiem „bez utworów zależnych" (ND-No Derivative Works) oraz możliwość wielokrotnego użycia i adaptacji materiałów w otwartym dostępie, co obniża koszty takich zasobów. Mimo oczywistych korzyści rozwój OZE przebiega w zróżnicowany sposób. Uwarunkowane jest to poziomem rozwoju danego kraju, stopniem dofinansowania instytucji zajmujących się edukacją. Niemniej OZE stają się standardem. $\mathrm{Na}$ gruncie polskim projekty rządowe mają charakter pilotażowy. Brak im kontynuacji i nadal są bardziej zachowawcze niż wymagają tego reguły $\mathrm{OZE}^{21}$. Dlatego to inicjatywy pozarządowe nadają ton polskiemu ruchowi OZE. Liderem jest Koalicja Otwartej Edukacji ${ }^{22}$ powołana przez Fundację Nowoczesna Polska, Interdyscyplinarne Centrum Modelowania Matematycznego i Komputerowego Uniwersytetu Warszawskiego (ICM UW), Stowarzyszenie Bibliotekarzy Polskich oraz Stowarzyszenie Wikimedia Polska. Dziś Koalicja liczy 30 członków. Jej działania koncentrują się na udostępnianiu wolnych zasobów, organizacji szkoleń promujących ideę otwartości w edukacji, a przede wszystkim udziale we wszelkich konsultacjach społecznych na temat prawnych aspektów polityki otwartościowej prowadzonych przez rząd.

OZE to w pierwszej kolejności wzrost jakości edukacji studentów. Ale jest to też szansa na kontakt z nauką dla szerokiego grona użytkowników. Osoby, które ukończyły już studia, a nie są związane zawodowo z nauką, hobbyści realizujący swoje pasje, mogą dzięki tym zasobom mieć kontakt $\mathrm{z}$ aktualnymi treściami naukowymi, a uczelnia być obecna $\mathrm{w}$ Internecie ${ }^{23}$ i powiększać obszar swojego oddziaływania. Nacisk na samokształcenie i uczenie się przez

${ }^{18}$ Creative Commons Polska, [dostęp: 8.04.2015], http://creativecommons.pl/poznajlicencje-creative-commons/.

${ }^{19} \mathrm{~K}$. Grodecka, J. Marković, J. Kusiak, Open AGH - otwarte zasoby edukacyjne $w$ praktyce, „E-mentor” 2012, nr 3 (45), [dostęp: 8.04.2015], http://www.e-mentor.edu.pl/ artykul/index/numer/45/id/936.

${ }^{20} 2150$ kursów, $125 \mathrm{mln}$ odwiedzających, stan na 8.04.2015, [dostęp: 8.04.2015], http:// ocw.mit.edu/about/.

${ }^{21}$ K. Grodecka, J. Marković, J. Kusiak, op. cit.

${ }^{22}$ Koalicja Otwartej Edukacji, [dostęp: 8.04.2015], http://koed.org.pl/pl/.

${ }^{23}$ P. Szczęsny, op. cit., s. 29. 
całe życie sprawiają, że zasoby te cieszą się rosnącym zainteresowaniem. $\mathrm{Na}$ uwagę zasługują Uniwersytet Wirtualny, pierwszy polski portal otwartych kursów akademickich ${ }^{24}$, otwarte materiały dydaktyczne stworzone w ramach projektu Opracowanie programów nauczania na odległość na kierunku studiów wyższych - Informatyka ${ }^{25}$, otwarte zasoby Portal Edukacyjny $\mathrm{UMK}^{26}$ czy Open $\mathrm{AGH}^{27}$.

Każda działalność biblioteki, szczególnie ta, która wiąże się z uruchomieniem nowych usług, powinna być poprzedzona badaniem oczekiwań użytkowników, do których są one adresowane. Wszelkie decyzje wdrożeniowe podejmowane na podstawie „mętnych wyobrażeń" ${ }^{28}$, skutkują brakiem oczekiwanych rezultatów, na przykład brakiem zwiększenia wykorzystania oferowanych zasobów. Materiały edukacyjne wydają się tą kategorią zbiorów bibliotecznych, która adresowana jest do bardzo konkretnej grupy odbiorców, studentów. Tym samym nie wymagają wyczerpujących badań na temat potrzeb informacyjnych. Osoby odpowiedzialne za ofertę informacyjną biblioteki muszą skoncentrować swoje wysiłki na pozyskaniu programów nauczania, które realizowane są na danej uczelni, dotarciu do wykazów przedmiotów i spisów literatury. Budowa własnych zasobów edukacyjnych, a następnie „otwartych zasobów edukacyjnych", staje się priorytetem. W tworzenie otwartych zasobów powinna aktywnie być włączona kadra dydaktyczna. Prezentacje, wykłady są bardzo często umieszczane na stronach internetowych wydziałów lub na prywatnych stronach wykładowców. Choć dostępne w Internecie, jednak adresowane są do wąskiego grona osób, to znaczy studentów konkretnego kierunku. Często mogą je zrozumieć tylko ci, którzy wcześniej brali udział w danych zajęciach. Zdarza się, że wykładowcy udostępniają zeskanowane notatki. Nie są to $z$ pewnością OZE w pełnym tego słowa znaczeniu. Ale odpowiednio opracowane i udostępniane w uczelnianym repozytorium, cieszyłyby się powodzeniem wśród studentów. Dodatkowo, tak jak inne publikacje, miałyby zapewnioną ochronę w postaci długoterminowej archiwizacji. Byłyby zdecydowanie bardziej „wi-doczne” i dostępne dla szerszego grona studentów, także spoza uczelni. Materiały przygotowane przez wykładowcę są sposobem na aktywne kreowanie procesu edukacji. Dają pewność, że studenci otrzymali optymalną dawkę wiedzy. Co więcej, mogą być konkretnym punktem odniesienia przy egzaminach lub innych formach oceny.

${ }^{24}$ Uniwersytet Wirtualny, [dostęp: 13.04.15], http://uniwersytet-wirtualny.edu.pl/.

${ }^{25}$ Studia informatyczne, [dostęp: 13.04.15], http://wazniak.mimuw.edu.pl/.

${ }^{26}$ Portal Edukacyjny UMK, [dostęp: 13.04.15], http://portal.umk.p1/.

${ }^{27}$ Otwarte Zasoby Edukacyjne Akademia Górniczo-Hutnicza w Krakowie, [dostęp: 13.04.15], http://open.agh.edu.pl/.

${ }^{28} \mathrm{D}$. Nicholas, Ocena potrzeb informacyjnych $w$ dobie Internetu: idee, metody, środki. Warszawa 2001, s. 17. 
Miarą sukcesu biblioteki będzie satysfakcja użytkowników ${ }^{29}$. Kluczem do satysfakcji użytkowników jest znajomość ich potrzeb ${ }^{30}$. Niezwykle szeroki zakres informacji, którą dostarcza Internet, tylko pozornie zaspokaja potrzeby informacyjne. Łatwość pozyskania informacji nie idzie w parze z jakością. Ktoś, kto „potrafi zapewnić równowagę między nastawieniem na informację a problemami pojawiającymi się w efekcie otrzymania jej nadmiaru"31 jest nader pożądany. Ilość dostępnej informacji, w połączeniu z brakiem czasu na jej efektywne selekcjonowanie, skutkuje często rezygnacją z poszukiwań. Można odnieść wrażenie, że niewielka, ale celowo dobrana doza informacji, byłaby wybawieniem dla wielu użytkowników. Nie zawsze ,im więcej informacji, tym więcej wiedzy"32. Dobrze przygotowane materiały dydaktyczne są dla studentów nieocenioną pomocą.

Rozwijanie i korzystanie z OZE natrafia na bariery ${ }^{33}$, których w literaturze znajdujemy trzy główne grupy:

1. Bariery prawne związane $\mathrm{z}$ niedostateczną wiedzą na temat otwartych licencji. Jakiekolwiek wątpliwości prawne, skutkują raczej rezygnacją $\mathrm{z}$ udostępniania $\mathrm{w}$ otwartym modelu niż poszukiwaniem właściwego rozwiązania problemu. Strach przed naruszeniem prawa sprawia, że nawet dozwolony użytek edukacyjny nie jest wykorzystywany.

2. Bariery świadomościowe. Ciągle spotyka się niechęć do dzielenia się efektami swojej pracy. Mówienie o korzyściach płynących z udostępniania wciąż postrzega się jako teoretyzowanie. Efekty otwierania zasobów widoczne są w dalszej perspektywie czasowej, nie mają charakteru fizycznego w postaci gratyfikacji finansowej czy szybkiego awansu. Dlatego proponowane $\mathrm{w}$ literaturze premiowanie, choćby przez przyznawanie dodatkowych punktów w okresowej ocenie pracownika przeprowadzanej na uczelni, mogłyby być pozytywnym bodźcem.

3. Bariery technologiczne należą do trzeciej grupy przeszkód na drodze rozwoju OZE. Technologia IT przeniknęła nasze życie prawie w każdym jego aspekcie. W wielu sytuacjach wiedza informatyczna jest jednak niewystarczająca. Pomoc w publikacji materiałów dydaktycznych w otwartym modelu, przynajmniej na początkowym etapie, często okazuje się wystarczająca. Poznanie przez autora procesu publikacji, nabycie nowych umiejętności na pewno podwyższy samoocenę, a tym samym może stanowić wystarczającą motywację. Przygoda z OZE przebiega często zgodnie ze schematem: wykorzystanie materiałów, które udostępnili inni w swojej pracy dydaktycznej, dostosowanie ich lub stworzenie własnych zasobów, dzielenie się nimi z innymi.

\footnotetext{
${ }^{29}$ Ibidem, s. 20.

${ }^{30}$ Ibidem, s. 21-22.

${ }^{31}$ Ibidem, s. 26-27.

${ }^{32}$ Ibidem, s. 56.

${ }^{33}$ K. Grodecka, J. Marković, J. Kusiak, op. cit.
} 


\section{Zasoby edukacyjne w repozytorium uczelnianym}

Repozytoria są najlepszym narzędziem do „otwierania” nauki w uczelni. Wraz z otwartymi czasopismami elektronicznymi stały się one głównymi propagatorami OA. Ich zadaniem jest gromadzenie $\mathrm{w}$ formie cyfrowej dorobku naukowego danej instytucji w postaci artykułów z czasopism (postprinty), materiałów niepublikowanych (preprinty), książek lub ich rozdziałów, materiałów konferencyjnych, prac magisterskich i doktorskich, surowych danych badawczych, materiałów audio-wideo, oprogramowania czy patentów ${ }^{34}$. Zawartość repozytoriów, choć generalnie bardzo podobna, w przypadku poszczególnych uczelni może być kształtowana zgodnie z potrzebami użytkowników, ale zawsze z poszanowaniem prawa autorskiego, które przy udostępnianiu tych materiałów ma zasadnicze znaczenie.

Według badań, które poprzedziły powstanie Repozytorium Uniwersytetu im. Adama Mickiewicza (AMUR) ${ }^{35}$ w repozytorium, obok artykułów naukowych i czasopism wydawanych na uczelni oraz prac doktorskich, powinny być gromadzone kolekcje materiałów dydaktycznych w formie rozdziałów z książek, skryptów i prezentacji multimedialnych, choć te ostatnie w mniejszym stopniu. Dodatkowo respondenci nie wyrazili zbytniej chęci ograniczenia korzystania z tych materiałów tylko do określonej grupy, na przykład „moich studentów”. W odpowiedzi na pytanie postawione przez autorki: „które z powodów nakłoniłoby Pana/Panią do deponowania prac w repozytorium?", pojawiła się opcja ,ułatwiłoby to dostęp do prac moim studentom”. Wybrała ją zdecydowana większość ankietowanych. Dostrzeganie deponowania prac w repozytorium nie tylko przez pryzmat własnych korzyści, takich jak wymiana myśli między naukowcami, zwiększenie cytowalności, autopromocja, uzyskanie grantu, premii, rozwój kariery, wzrost prestiżu na uczelni ${ }^{36}$, ale także jako sposobu dzielenia się z pożytkiem dla innych, napawa optymizmem.

Promocja działalności naukowej uczelni, zwiększenie widoczności w Internecie, a co się z tym wiąże wzrost odwiedzin na stronach WWW uczelni, zarządzanie zasobami naukowymi i monitorowanie ich jakości, gromadzenie i zabezpieczanie dorobku naukowego uczelni, pomoc przy parametryzacji, wsparcie dla dydaktyki to ważne argumenty dla władz uczelnianych, które trzeba wyeksponować pozyskując zwolenników idei powstania uczelnianego repozytorium. Zrozumienie dla tej idei i jej poparcie wyrażone w konkretnych zarządzeniach władz uczelni, jest kluczowe dla każdego takiego projektu. Grupą, której akceptacja i zaangażowanie w tworzenie repozytorium stanowi gwarancję sukcesu, są pracownicy naukowi uczelni. Bez ich współpracy nie może być

${ }^{34}$ B. Bednarek-Michalska, op. cit., s. 8.

${ }^{35}$ M. Rychlik, E. Karwasińska, Projekt powołania repozytorium Uniwersytetu im. Adama Mickiewicza w Poznaniu. Badanie ankietowe postaw pracowników naukowych, s. 6, [dostęp: 10.04.2015], https://repozytorium.amu.edu.pl/jspui/handle/10593/434.

${ }^{36}$ Ibidem, s. 11. 
mowy o rozwoju takiego przedsięwzięcia. Deponowanie publikacji w repozytorium może być na początku postrzegane przez nich jako dodatkowe obciążenie. Obowiązek zamieszczania dorobku w repozytorium jest najefektywniejszym sposobem powiększania zasobu. Dobrze zaplanowana i przeprowadzona akcja informacyjno-promocyjna sprawi, że nawet obowiązek umieszczania prac w repozytorium spotka się ze zrozumieniem i akceptacją naukowców. Zasada otwartości nie jest generalnie kwestionowana przez środowisko bibliotekarzy. Jej realizacja przebiega jednak w zróżnicowany sposób, jest uzależniona od możliwości organizacyjnych i finansowych, jakimi dysponują poszczególne biblioteki.

Zasoby edukacyjne nie mają stricte naukowego charakteru, więc nie należą bezpośrednio do świata nauki ${ }^{37}$, ale poprzez zadanie jakie spełniają $\mathrm{w}$ dydaktyce uczelni, ich miejsce w bibliotece, a obecnie również w repozytorium, jest jak najbardziej usprawiedliwione. Umieszczanie ich w repozytoriach nie stanowi jeszcze dominującej tendencji. Owszem, repozytoria posiadają kolekcje Materiały dydaktyczne, jednak nie są one zbyt bogate. Być może wynika to $\mathrm{z}$ faktu, że budowa zasobu repozytorium uczelnianego koncentruje się w pierwszej kolejności na dorobku naukowym pracowników, czasopismach wydawanych przez uczelnię. Dodatkowo, pracownicy naukowi prowadząc zajęcia ze studentami bazują na materiałach przygotowanych na własny użytek, nie myśląc o ich upublicznianiu. Stan ten będzie z pewnością ulegał zmianie. W 2013 r. została podjęta wspólna uchwała Konferencji Rektorów Akademickich Szkół Polskich (KRASP) i Polskiej Akademii Nauk (PAN) w sprawie „Zasad otwartego dostępu do treści publikacji naukowych i edukacyjnych" ${ }^{38}$. Postuluje ona przyjęcie OA jako podstawowego modelu udostępniania publikacji. Podkreśla potrzebę wydania odpowiednich aktów prawnych. Dodatkowo zaleca, aby aktywność na rzecz szerokiego otwierania zasobów była brana pod uwagę przy indywidualnych ocenach naukowców i jednostek naukowych.

Umieszczanie zasobów edukacyjnych $\mathrm{w}$ repozytorium i otwieranie ich, może sprawiać wrażenie, że bibliotekarze pogodzili się z brakiem fizycznej obecności użytkownika w bibliotece. Poszerzanie oferty o możliwość korzystania $\mathrm{w}$ Internecie z niektórych zasobów bibliotecznych, nie musi być równoznaczne ze zmniejszeniem statystyki odwiedzin. Korzystając z repozytorium uczelnianego lub z jakichkolwiek zasobów biblioteki dostępnych w sieci, student powinien być świadomy, że korzysta z biblioteki, ale wirtualnie. Może kontakt wirtualny rozbudzi chęć kontaktu rzeczywistego? Skrypty, laboratoria, ćwiczenia to materiały wydawane przez wydawnictwa uczelniane, adresowane bezpośrednio do studentów. Prawa autorskie do tych publikacji zostały bardzo

\footnotetext{
${ }^{37}$ P. Szczęsny, op. cit., s. 22.

${ }^{38}$ Stanowisko Prezydium KRASP i Prezydium PAN z dnia 5 lipca 2013 r. w sprawie zasad otwartego dostępu do treści publikacji naukowych i edukacyjnych, [dostęp: 10.04.2015], http:// www.aktualnosci.pan.pl/images/stories/pliki/2013/Wiadomo\%C5\%9Bci_biez/stanowisko_KRA SP-PAN_open_access.pdf.
} 
często przekazane wydawcy. Współpraca $\mathrm{z}$ wydawnictwem uczelnianym $\mathrm{w}$ celu otrzymania licencji na udostępnienie tych materiałów w repozytorium jest bardzo wskazana. Na podstawie porozumienia $\mathrm{z}$ Wydawnictwami Uczelnianymi Uniwersytetu Technologiczno-Przyrodniczego w Bydgoszczy udostępniono w Repozytorium Cyfrowym UTP (RC UTP) serię Rozprawy Habilitacyjne. Obecnie trwa proces publikacji monografii pracowników uniwersytetu wydanych przez Wydawnictwa. Podjęto próby uzyskania zgody na zdeponowanie i udostępnienie $\mathrm{w}$ repozytorium podręczników autorstwa pracowników UTP dla studentów kierunku bioinżynieria medyczna, w ramach projektu Kierunek Przyszłości - Inżynieria Biomedyczna, współfinansowanego przez Narodowe Centrum Badań i Rozwoju.

\section{Nowe możliwości dla biblioteki uczelnianej}

W literaturze odnajdujemy stwierdzenie, iż to współpraca menedżera repozytorium z bibliotekarzami, którzy posiadają doświadczenie i umiejętności, zapewni w pierwszej kolejności „efektywne funkcjonowanie repozytorium”39. W praktyce łatwiej znaleźć potwierdzenie tezy, że to biblioteki jako jednostki najbardziej „,merytorycznie przygotowane do tego działania" ${ }^{40}$ pełnią kluczową rolę w budowaniu i zarządzaniu repozytorium uczelnianym. Najczęściej to ich pracownicy wykonują prace koncepcyjne ${ }^{41}$. Inicjatywa, jaką w tej dziedzinie wykaże biblioteka, może być dla niej szansą na wzmocnienie swojej pozycji w strukturze uczelni, pozytywną zmianą w postrzeganiu jej przez władze uczelni. Biblioteka nie będzie narażona jako pierwsza na oszczędności w postaci zmniejszania budżetu czy zatrudnienia ${ }^{42}$.

Pracownicy naukowi deponujący swoje prace w repozytorium tworzą wirtualną społeczność instytucji. W literaturze przedmiotu znajdujemy określenie „kultura partycypacji”, ${ }^{33}$. Biblioteka stwarzając naukowcom możliwość publikowania w repozytorium uczelnianym wspomaga tę kulturę. Dostęp do wiedzy

\footnotetext{
${ }^{39}$ M. Rychlik, E. Karwasińska, Projekt powołania repozytorium Uniwersytetu im. Adama Mickiewicza w Poznaniu. Badanie ankietowe postaw pracowników naukowych, s. 1, [dostęp: 9.04.2015], https://repozytorium.amu.edu.pl/jspui/handle/10593/434.

${ }^{40}$ B. Bednarek-Michalska, op. cit., s. 49.

${ }^{41}$ M. Rychlik, Wptyw repozytorium instytucjonalnego na upowszechnianie dorobku naukowego uczelni, s. 2, [dostęp: 9.04.2015], https://repozytorium.amu.edu.pl/jspui/handle/10593 18054 .

${ }^{42}$ B. Feret, Biblioteka hubem uczelni? Nowe czasy - nowe wyzwania Library as university hub? New time, new challenges, [w:] Otwarte zasoby wiedzy. Nowe zadania uczelni i bibliotek w rozwoju komunikacji naukowej. Materiały konferencyjne, Kraków-Zakopane, 15-17 czerwca 2011, praca zbiorowa pod red. M.M. Górskiego i M. Marcinek. Kraków 2011, s. 260.

${ }^{43}$ E. Karwasińska, M. Rychlik, Model i etapy tworzenia repozytorium instytucjonalnego na podstawie badań własnych i doświadczeń bibliotek zagranicznych Institutional repository model and stages of its development based on individual research project and experiences of foreign libraries, s. 2, [dostęp: 9.04.2015], https://repozytorium.amu.edu.pl/jspui/handle/105 93/120.
} 
wytwarzanej na uczelni pozwala na skoordynowanie wysiłku całej społeczności naukowej. Być może osoby, z którymi trzeba nawiązać współpracę naukową pracują w tej samej uczelni, a wymianę doświadczeń można zacząć od najbliższego otoczenia. Świadomość bycia częścią zespołu na pewno działa mobilizująco. Współpraca ze społecznością akademicką, pracownikami naukowymi w szczególności zawsze należała do trudnych. Jacek Wojciechowski ${ }^{44}$ kładzie to na karb „silnej bariery wzajemnych uprzedzeń, niechęci i błędnych przeświadczeń". Mimo trudności nie ma dziś innej drogi dla biblioteki uczelnianej, jak współpraca i bycie partnerem w stworzeniu prawdziwego „zaplecza komunikacyjnego" czy dostosowaniu się do standardów i programów edukacyjnych $^{45}$. Można uznać, że wszystkie potrzebne informacje odnośnie dydaktyki, bibliotekarz znajdzie w sylabusach. Niestety, ich mnogość i zmienność nie ułatwiają zadania. Bezpośrednia sugestia wykładowcy jest tu na wagę złota.

Bibliotekarze generalnie przyjęli już zasady otwartości, czego dowodem jest powstanie i rozwój repozytoriów na uczelniach wyższych. Ciągle brakuje wiedzy w środowisku naukowców. Naiwnością byłoby sądzić, że sami sięgną po informacje z zakresu OA. Starsi pracownicy naukowi, którzy przetarli ścieżki publikacji w tradycyjnej formie, przywykli raczej do zamkniętego modelu uprawiania nauki, nie chcą zmian. Inicjatywa leży po stronie bibliotek. Szkolenia i warsztaty powinny mieć charakter cykliczny. Ich zakres musi być poszerzany o aktualną wiedzę z zakresu wolnych zasobów. To jest obszar, gdzie naukowcy powinni spotkać się z bibliotekarzami jako partnerami.

W czasie takich szkoleń łatwiej zachęcić do umieszczania w repozytorium nie tylko publikacji naukowych, ale też materiałów dydaktycznych. Należałoby się zastanowić, czy nie poszerzyć oferty szkoleń o tematykę przygotowywania takich materiałów z wykorzystaniem techniki komputerowej. Ich mała liczba w wolnym dostępie może wynikać z prozaicznej przyczyny - braku odpowiednich umiejętności w opracowywaniu i posługiwaniu się nimi w dydaktyce.

Repozytorium uczelniane jako platforma dla wszelkich materiałów dydaktycznych powstających na uczelni jest na pewno ciekawą propozycją. Rozbudowa kolekcji dydaktycznej przez zespół redakcyjny repozytorium, a w konsekwencji przez bibliotekę, przyczyni się z pewnością do wzrostu użytkowników. Możliwości jakie stwarza implementacja modelu OA i OZE są szansą dla bibliotek uczelnianych. Pociągają one zmiany, nie zawsze od razu widoczne. Nie zawsze mają one charakter czysto techniczny, ekonomiczny czy prawny. Najtrudniejszymi do zaakceptowania są zmiany kulturowe, a do takich zmian należy otwartość w nauce czy szeroko pojętej edukacji.

Komunikowanie wartości biblioteki już nie przez wielkość zasobu bibliotecznego, ale prezentacja różnorodnej oferty dla społeczności uczelnianej jest

\footnotetext{
${ }^{44}$ J. Wojciechowski, Biblioteki w nowym otoczeniu, Warszawa 2014, s. 159.

${ }^{45}$ Ibidem, s. 160 i n.
} 
dziś dla niej wyzwaniem i szansą ${ }^{46}$. Wobec nowych wyzwań bibliotekarz staje się wdrożeniowcem, konsultantem. Propagując ideę otwartości sam powinien być osobą otwartą, kreatywną. Wykształcenie bibliotekarskie musi być wspomagane kompetencjami informacyjnymi i komunikacyjnymi oraz uzupełniane wiedzą z zakresu informatyki. Wyzwania, które stają przed biblioteką uczelnianą są tak naprawdę nowymi możliwościami do realizowania podstawowej misji. Gromadzenie, opracowywanie, udostępnianie - podstawy zostają takie same, a tak wiele się zmienia.

\section{Bibliografia}

Bednarek-Michalska B., Rola bibliotek naukowych we wdrażaniu rozwiazań otwartych. Repozytorium Open Access - model dla uczelni, [w:] Otwarte zasoby wiedzy. Nowe zadania uczelni i bibliotek w rozwoju komunikacji naukowej. Materialy konferencyjne, KrakówZakopane, 15-17 czerwca 2011, praca zbiorowa pod redakcją M.M. Górskiego i M. Marcinek. Kraków 2011, [dostęp: 14.04.2015] http://www.nowyebib.info/images/stories/ Mat_konferencyjne/23/konferencjaozw_2011_calosc.pdf.

Creative Commons Polska, [dostęp: 8.04.2015], http://creativecommons.pl/poznaj-licencjecreative-commons/.

Czyżewska M., Wizerunek biblioteki a przewaga konkurencyjna szkót wyższych, [w:] Ksztaltowanie wizerunku biblioteki, Białystok 2007.

Feret B., Biblioteka hubem uczelni? Nowe czasy - nowe wyzwania Library as university hub? New time, new challenges, [w:] Otwarte zasoby wiedzy. Nowe zadania uczelni i bibliotek w rozwoju komunikacji naukowej. Materiaty konferencyjne, Kraków-Zakopane, 15-17 czerwca 2011, praca zbiorowa pod redakcją M.M. Górskiego i M.Marcinek. Kraków 2011, [dostęp: 14.04.2015], http://www.nowyebib.info/images/stories/Mat_konferencyjne/23/ konferencjaozw_2011_calosc.pdf.

Grodecka K., Marković J., Kusiak J.: Open AGH - otwarte zasoby edukacyjne w praktyce, „E-mentor” 2012 nr 3(45), [dostęp: 8.04.2015], http//www.e-mentor.edu.pl/artykul/index/ numer/45/id/936.

Hofmokl J., Tarkowski A., Bednarek-Michalska B., Siewicz K., Szprot J., Przewodnik po otwartej nauce, ICM, Warszawa 2009, [dostęp: 14.04.2015], http://ceon.pl/images/ przewodnik_po_otwartej_nauce.pdf.

Karwasińska E., Karwasiński P., Ksztaltowanie nowej tożsamości bibliotekarza w erze zmian technologicznych $i$ mobilności uslug bibliotecznych, [dostęp: 10.04.2015], https:// repozytorium.amu.edu.pl/jspui/bitstream/10593/7884/1/Emilia_Karwasi\%C5\%84ska_Piotr \%20Karwasi\%C5\%84ski_Kszta\%C5\%82towanie nowej to\%C5\%BCsamo\%C5\%Bci.pdf.

Karwasińska E., Rychlik M., Model i etapy tworzenia repozytorium instytucjonalnego na podstawie badań własnych i doświadczeń bibliotek zagranicznych Institutional repository model and stages of its development based on individual research project and experiences of foreign libraries, [dostęp: 9.04.2015], https://repozytorium.amu.edu.pl/jspui/ handle/10593/120.

\footnotetext{
${ }^{46}$ E. Karwasińska, P. Karwasiński, Kształtowanie nowej tożsamości bibliotekarza $w$ erze zmian technologicznych i mobilności uslug bibliotecznych, [dostęp: 10.04.2015], https:// repozytorium.amu.edu.pl/jspui/bitstream/10593/7884/1/Emilia_Karwasi\%C5\%84ska_Piotr\% 20Karwasi $\%$ C5\%84ski_Kszta\%C5\%82towanie_nowej_to $\%$ C5\%BCsamo\%C5\%9Bci.pdf.
} 
Koalicja Otwartej Edukacji, [dostęp: 8.04.2015], http://koed.org.pl/otwartosc/otwartaedukacja/.

Nicholas D., Ocena potrzeb informacyjnych $w$ dobie Internetu: idee, metody, środki, Warszawa 2001 .

Marketing szkół wyższych, red. G. Nowaczyk, M. Kolasiński, Poznań 2004.

Ratajczak P., Sojkin B., Ksztaltowanie pozycji konkurencyjnej szkoły wyższej i jej oferty edukacyjnej, [w:] Marketing szkół wyższych, Poznań 2004.

Rychlik M., Wpływ repozytorium instytucjonalnego na upowszechnianie dorobku naukowego uczelni, [dostęp: 9.04.2015], https://repozytorium.amu.edu.pl/jspui/handle/10593/8054.

Rychlik M., Karwasińska E., Projekt powołania repozytorium Uniwersytetu im. Adama Mickiewicza w Poznaniu. Badanie ankietowe postaw pracowników naukowych, [dostęp: 10.04.2015], https://repozytorium.amu.edu.pl/jspui/handle/10593/434.

Spychała P., Szlachcic M., Wudarzewski T., Wykorzystanie aktywnych form dydaktycznych w działalności promocyjnej uczelni, [w:] Marketing szkół wyższych, Poznań 2004.

Suber P., Otwarty dostęp, Warszawa 2014, [dostęp: 10.04.2015], http://pon.edu.pl/index.php/ nasze-publikacje?pubid $=14$.

Szczęsny P., Otwarta nauka czyli dobre praktyki uczonych, Toruń 2013.

Wojciechowski J., Biblioteki w nowym otoczeniu, Warszawa 2014.

Zeller P., Proces oceny jakości ustug szkoty wyższej z perspektywy studenta, [w:] Marketing szkół wyższych, Poznań 2004. 